\title{
Plasma Adrenocorticotropin, Cortisol, and Dehydroepiandrosterone Response to Corticotropin-Releasing Factor in Normal Children during Pubertal Development
}

\author{
ANDREA ATTANASIO, RALF ROßKAMP, SERGIO BERNASCONI, CESARE TERZI, \\ MICHAEL B. RANKE, GIORGIO GIOVANELLI, AND DEREK GUPTA \\ Department of Diagnostic Endocrinology, University Childrens Hospital, Tübingen, and Kinderklinik, \\ Bonn, FRG [R.R.]; and Clinica Pediatrica dell'Università, Parma, Italy [S.B., G.G.]
}

\begin{abstract}
The adrenocorticotropin (ACTH), cortisol, and dehydroepiandrosterone responses to synthetic human corticotropin-releasing factor (CRF) were studied in 28 endocrinologically healthy children (age 1-16 yr) and in six adult volunteers (age 24-42 yr). CRF was given as an intravenous bolus $(1 \mu \mathrm{g} / \mathrm{kg}$ body weight) between 0900 and $1000 \mathrm{hr}$. Significant increments in ACTH and cortisol levels after CRF were observed in all subjects, with an ACTH peak value of $48.2 \pm 3.4 \mathrm{pg} / \mathrm{ml}$ at $10 \mathrm{~min}(p<$ 0.001). The ACTH and cortisol response patterns after CRF did not change with age or pubertal maturation and did not differ in children and in adults. In contrast, the dehydroepiandrosterone response to CRF clearly was related to the stage of pubertal development. The peak value after CRF significantly increased from puberty stage 1 to puberty stage $5(164 \pm 18$ versus $779 \pm 86 \mathrm{ng} / 100 \mathrm{ml}, p<$ 0.001 ). In adults, the mean dehydroepiandrosterone peak value after CRF did not differ from that of P5 children. These results show that CRF can be given safely to children. The absence of age-dependent ACTH and cortisol responses and a dehydroepiandrosterone response changing with pubertal maturation points to the existence of factors involved in the control of adrenal androgen production other than ACTH. (Pediatr Res 22: 41-44, 1987)
\end{abstract}

Abbreviations

ACTH, adrenocorticotropin

DHEA, dehydroepiandrosterone

CRF, corticotropin-releasing factor

Since the isolation and characterization of CRF (1-3) several studies of its use in humans have been published (4-11). Synthetic CRF 1-41 has been reported to be highly potent in stimulating the release of ACTH- and proopiomelanocortinderived peptides from the pituitary of rodents and of humans $(12,13)$. Furthermore, the CRF-induced ACTH increase stimulates the concomitant release of cortisol and aldosterone from the adrenals $(4-11,14)$. Because of these effects and of its relative safety during clinical studies, CRF provides a powerful tool for studying ACTH secretion in normal as well as pathological

Received July 17, 1986; accepted February 2, 1987.

Correspondence Professor D. Gupta, Department of Diagnostic Endocrinology, University Childrens Hospital, Rümelinstraße 23 D-7400 Tübingen, FRG.

C.T. is a recipient of a research fellowship from the University of Parma, Parma, Italy. situations. Several recent studies describe use of the CRF test in the evaluation of Cushing syndrome (15-17), Nelson syndrome $(19$, isolated pituitary ACTH deficiency and adrenal insufficiency $(19,20)$. Data on the administration of CRF to children are limited so far to two reports $(21,22)$. In one study, Ross et al. (21) could find no age-dependent changes in the ACTH or cortisol responses to CRF in a group of normal children.

In the present study, CRF was administered to hospitalized but endocrinologically healthy children, and the CRF-induced activation of the pituitary-adrenal axis was studied in relation to pubertal maturation. DHEA responses as well as ACTH and cortisol responses to CRF were assessed since the maturation of adrenal androgen production is associated with pubertal development (23-26).

\section{SUBJECTS AND METHODS}

Subjects. Approval for studies was obtained from the ethical committees of the three pediatric clinics in Tübingen, Bonn, and Parma. The parents of all hospitalized but endocrinologically healthy children gave informed consent before the test was done. The normal children had no physical abnormalities except short stature. According to the pubic hair stages of Tanner, nine children, all males, were in puberty stage 1 , nine (six males and three females) were in puberty stage 2 , and 10 (six males and four females) were in puberty stage 4 to 5 . Additionally, six normal adult volunteer subjects (age 24-42 yr) were included.

$C R F$ stimulations test. Human synthetic CRF 1-41 was obtained from Bissendorf Peptide (Wedemark, FRG). The peptide was dissolved in saline and given at a dose of $1 \mu \mathrm{g} / \mathrm{kg}$ body weight as an intravenous bolus between 0900 and $1000 \mathrm{~h}$. Blood samples for ACTH, cortisol, and DHEA measurements were obtained $15 \mathrm{~min}$ before, immediately before, and 5, 10, 15, 30, $60,90,120$, and $180 \mathrm{~min}$ after CRF administration. The samples were collected in prechilled polystyrene tubes containing EDTA, placed on ice, and centrifuged $10 \mathrm{~min}$ later. Aliquots for measurements of ACTH, cortisol, and DHEA were separately frozen at $-30^{\circ} \mathrm{C}$ until assay.

Hormone assays. ACTH was measured in unextracted plasma by the RIAmat Kit of Byk Mallinckrodt (Dietzenbach, FRG). The antibody used in the RIA is specific for the 11-24 sequence of ACTH. Intra- and interassay coefficients of variation were 7 and $8.5 \%$ respectively; the sensitivity was $5 \mathrm{pg} / \mathrm{ml}$. The cortisol radioimmunoassay was performed with a MAIA kit provided by Serono (Freiburg, FRG). Intra- and interassay coefficients of variation of this method were 4.6 and $5.6 \%$. DHEA was measured by a kit manufactured by Wien Laboratories (Succasunna, $\mathrm{NJ}$ ) and supplied by DRG Instruments (Marburg, FRG). The coefficients of variation of this method were 6 and $11 \%$. 
Statistical analysis. Results are expressed as mean \pm SEM. For undetectable hormone concentrations the value of the detection limit of the method was taken (i.e. $5 \mathrm{pg} / \mathrm{ml}$ for ACTH, 0.3 $\mu \mathrm{g} / \mathrm{ml}$ for cortisol, and $50 \mathrm{ng} / \mathrm{ml}$ for DHEA). For statistical analysis, paired (within group differences) and unpaired (between group differences) Student's $t$ tests were applied, as the samples were found to be normally distributed.

\section{RESULTS}

At the dose of $1 \mu \mathrm{g} / \mathrm{kg}$ body weight CRF produced no side effects in most children and was well tolerated by all children. A flush lasting about $20 \mathrm{~min}$ was observed once in a 7-year-old boy. The ACTH and cortisol responses in the 28 children are given in Figure 1. ACTH control levels showed considerable variation (range: at $-15 \mathrm{~mm} 5.0-58.0$, at 0 time $5.0-39.4 \mathrm{pg}$ / $\mathrm{ml}$ ), and although in most subjects the $-15 \mathrm{~min}$ value was higher than the 0 value, the mean values did not differ significantly $(22.5 \pm 3.4$ versus $19.7 \pm 2.1 \mathrm{pg} / \mathrm{ml}$, NS). After CRF the mean ACTH levels significantly $(p<0.01)$ rose in all subjects to a peak value of $48.2 \pm 3.4 \mathrm{pg} / \mathrm{ml}$ at $10 \mathrm{~min}$ and decreased to $32.8 \pm 3.2$ and to $30.0 \pm 3.5 \mathrm{pg} / \mathrm{ml}$ at 15 and $30 \mathrm{~min}$. These values were significantly $(p<0.05)$ higher than the control values.

The cortisol levels showed less variation. As with ACTH, the -15 min value was higher than the 0 value in almost all subjects, but the mean values did not differ significantly $(13.9 \pm 1.2$ versus $11.3 \pm 0.8 \mu \mathrm{g} / 100 \mathrm{ml}, \mathrm{NS})$. After CRF, cortisol levels rose to a peak value of $20.2 \pm 0.8 \mu \mathrm{g} / 100 \mathrm{ml}(p<0.001)$ at $30 \mathrm{~min}$ and progressively declined thereafter. The ACTH and cortisol response patterns in the six adult volunteers did not differ from those in children (data not shown). When the ACTH and cortisol peak levels after CRF were related to the pubertal stage of the subjects, no differences were observed between prepubertal, pubertal, and adult subjects (Fig. 2).
In contrast, significant differences emerged in the DHEA response to CRF. In all subjects CRF elicited a clear increase in DHEA levels, the peak value occurring at 30 to 60 min postinjection. While DHEA control levels significantly increased throughout puberty (from $88.7 \pm 12$ at $\mathrm{P} 1$ to $594 \pm 48 \mathrm{ng} / 100$ $\mathrm{ml}$ at $\mathrm{P} 5, p<0.001)$, the peak DHEA levels after CRF significantly increased from P1 to P2 (164 \pm 18 versus $392 \pm 39 \mathrm{ng} /$ $100 \mathrm{ml}, p<0.001)$ and from P2 to P4-5 (779 $\pm 86, p<001)$ (Table 1 and Fig. 2). The DHEA peak value seen in adults after CRF $(723 \pm 78 \mathrm{ng} / 100 \mathrm{ml})$ did not differ from that seen in P45 subjects.

\section{DISCUSSION}

CRF stimulation in children induces an ACTH increase which is comparable to that seen in adults, as shown in a recent report of Ross et al. (21). These authors measured ACTH and cortisol levels every $30 \mathrm{~min}$ after CRF stimulation and found that the peak value of these two response parameters occurred at 30 min. In the present study, taking the blood samples at shorter intervals after CRF, it becomes evident that the ACTH peak occurs earlier and that the response pattern is biphasic. There is a rapid and steep ACTH increase immediately after CRF followed by a prompt decrease. At 15 or $30 \mathrm{~min}$ after CRF, ACTH mean levels are already $30 \%$ lower than at $10 \mathrm{~min}$ although significantly elevated when compared to the mean basal level. This pattern of response, which was not age dependent, suggests the existence of two pools of pituitary ACTH, one which is very quickly releasable. Although many studies have alread been performed in different clinical entities, this finding has been stressed previously by other authors. In our opinion, knowledge of such an ACTH response pattern might be of importance in the interpretation of CRF tests in pathological subjects in which a discrepancy exists between the ACTH and cortisol responses (18). In

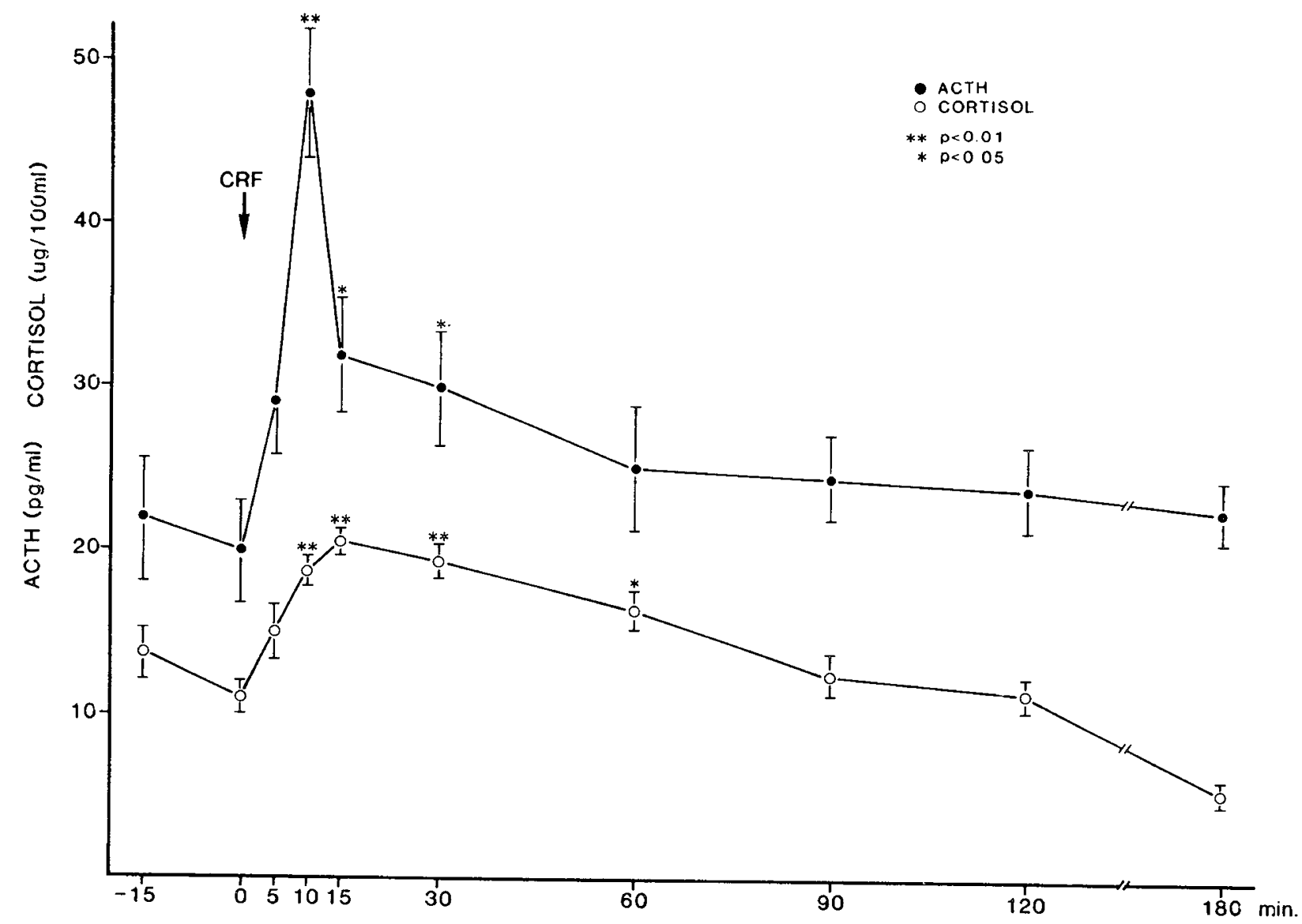

Fig. 1. Mean \pm SEM; plasma ACTH $(\bullet)$ and cortisol $(O)$ concentrations after CRF ( $1 \mu \mathrm{g} / \mathrm{kg}$ body weight) in 28 normal children. 


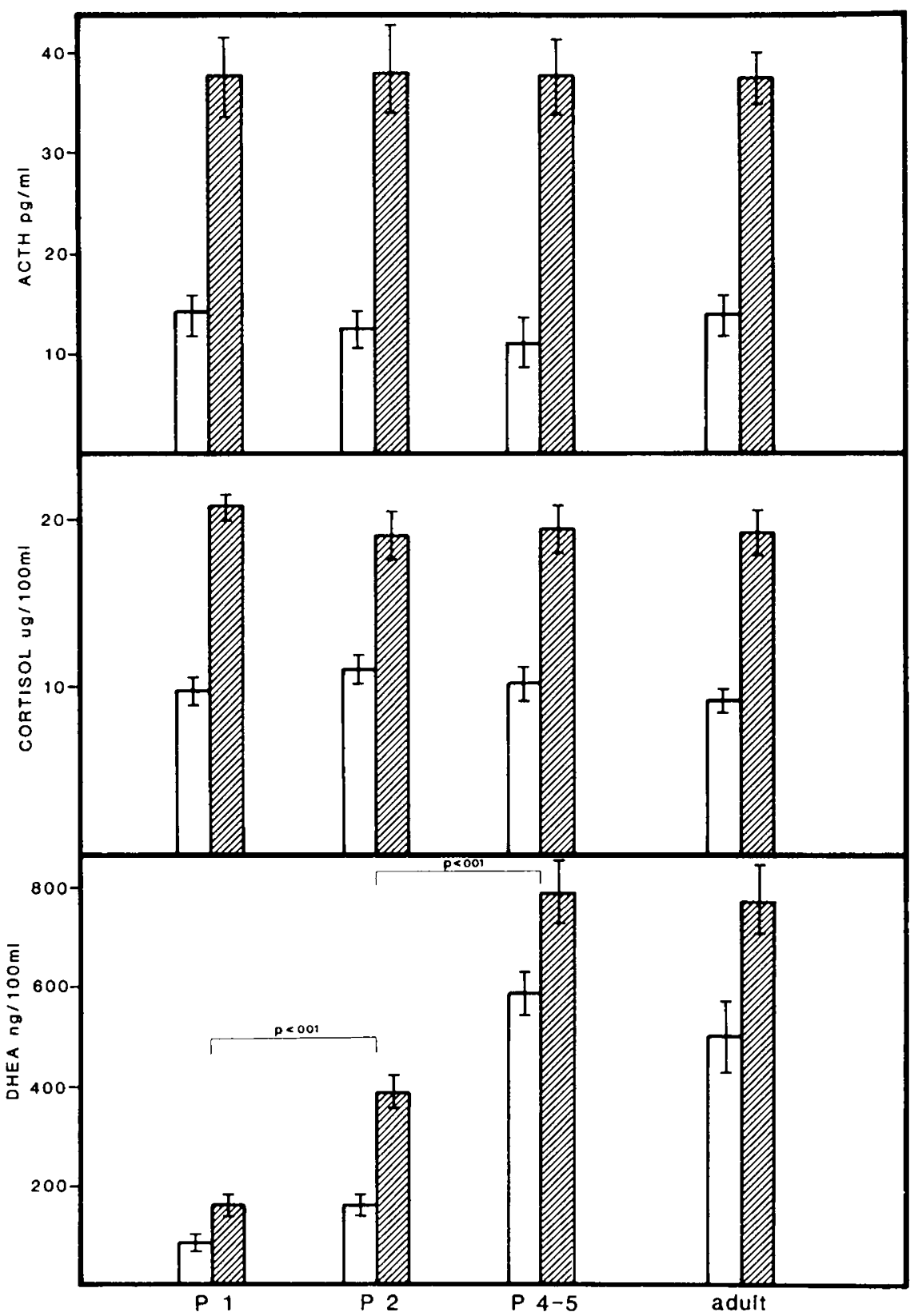

Fig. 2. Mean \pm SEM; ACTH, cortisol, and DHEA concentrations before and after CRF administration in normal children and adult volunteers. Open bars, control values; hatched bars, peak values. The groups are the same as in Table 1.

Table 1. Mean \pm SEM plasma DHEA concentrations $(\mathrm{ng} / 100 \mathrm{ml})$ before and after CRF stimulation $(1 \mu \mathrm{g} / \mathrm{kg}$ body wt)

\begin{tabular}{crcccc}
\hline \multicolumn{1}{c}{ Min } & \multicolumn{1}{c}{0} & \multicolumn{1}{c}{15} & 30 & \multicolumn{1}{c}{60} & 90 \\
\hline $\mathrm{P}_{1}(n=9)$ & $87 \pm 12$ & $152 \pm 19^{*}$ & $164 \pm 18^{*}$ & $121 \pm 17$ & $118 \pm 8$ \\
$\mathrm{P}_{2}(n=9)$ & $158 \pm 16$ & $281 \pm 27^{*}$ & $392 \pm 39 \dagger$ & $365 \pm 31^{*}$ & $172 \pm 18$ \\
$\mathrm{P}_{4}(n=10)$ & $594 \pm 48$ & $647 \pm 48$ & $779 \pm 86^{*}$ & $701 \pm 37^{*}$ & $611 \pm 15$ \\
Adult $(n=6)$ & $502 \pm 39$ & $632 \pm 45^{*}$ & $711 \pm 52^{*}$ & $723 \pm 78^{*}$ & $545 \pm 31$ \\
\hline
\end{tabular}

$* p<0.05$ over the 0 value.

$\dagger p<0.001$ over the 0 value.

most children, ACTH and cortisol control levels ( -15 value) are markedly elevated, sometimes in the range of the post-CRF levels. This observation is due to stressful stimuli (venipuncture) which are probably much stronger in children than in adults.

Although there are no changes in ACTH and cortisol responses to $\mathrm{CRF}$ related to pubertal maturation, as previously stressed by Ross et al. (21), the DHEA response is clearly related to pubertal developmental stage. This response is similar to that in children when the adrenals are stimulated with exogenous ACTH (2326). The DHEA peak value under CRF stimulation progressively increases from puberty stage 1 to puberty stage 4-5. As we observed in a previous study done with exogenous ACTH stimulation (23), DHEA responsiveness to CRF also is highest at puberty stage 2 (Fig. 2). Since the ACTH and cortisol responses 
to CRF do not change with age, it may be concluded that the observed DHEA response is due to some other, yet unknown, factor(s) directly involved with adrenal androgen production. The results of the present study show that CRF can be used to test the pituitary adrenal axis in children as in adults. It activates the pituitary-adrenal axis stimulating release of ACTH, cortisol, and DHEA. Therefore its diagnostic use might be extended to disturbances of pubertal development related to adrenal function.

\section{REFERENCES}

1. Vale W, Spiess J, Rivier C, Rivier J 1981 Characterisation of a 41-residue ovine hypothalamic peptide that stimulates secretion of corticotropin and $\beta$ endorphin. Science 213:1394

2. Spiess J, Rivier J, Rivier C, Vale W 1981 Primary structure of corticotropin releasing factor from ovine hypothalamus. Proc Natl Acad Sci USA 78:6517

3. Vale W, Rivier C, Brown MR, Spiess J, Koob J, Swanson L, Blizikijan L, Bloom F, Rivier E 1983 Chemical and biological characterization of corticotropin releasing factor. Rec Prog Horm Res 39:245-269

4. Grossmann A, Kruseman ACN, Perry L, Tomlin S, Shally AV, Besser GM 1982 New hypothalamic hormone, corticotropin releasing factor, specifically stimulates the release of adrenocorticotropic hormone and cortisol in man. Lancet 1:921-922

5. Orth DN, Jackson RV, DeCherney GS, DeBold CR, Uderman H, Alexander HN, Island DP, Rivier J, Rivier C, Spiess J, and Vale W 1983 Effect of synthetic ovine corticotropin releasing factor. $J$ Clin Invest 71:587-595

6. Nicholson WE, DeCherney GS, Jackson RV, DeBold CR, Uderman H, Alexander HN, Rivier J, Vale W, Orth DN 1983 Plasma distribution, disappearance half time, metabolic clearance rate, and degradation of corticotropin releasing factor in man. J Clin Endocrinol Metab 57:1263-1269

7. Copinschi G, Beyloos M, Bosson D, Desir D, Golstein J, Robyn C, Linkovski P, Mendlewicz J, Franckson JRM 1983 Immediate and delayed alterations of adrenocorticotropin and cortisol nyctohemeral profiles after corticotropin releasing factor in normal men. J Clin Endocrinol Metab 57:1287-1291

8. Chrousos GP, Nieman L, Nisula B, Schulte HM, Oldfield EH, Gold PW, Cutler JB, Loriaux DL 1984 Corticotropin releasing factor test. N Engl $\mathbf{J}$ Med 311:472-473

9. Schulte HM, Chrousos GP, Oldfield EH, Gold PW, Cutler GB Jr Loriaux DL 1985 Ovine corticotropin releasing factor administration in normal men: pituitary and adrenal responses in the morning and in the evening. Horm Res (Basel) 21:69-74

10. Schulte HM, Chrousos GP, Gold PW, Booth JD, Oldfield EH, Cutler JB Jr, Loriaux DL 1985 Continuous administration of synthetic corticotropin releasing factor in man. Physiological and pathophysiological implications. J Clin Invest 75:1781-1785

11. DeBold CR, DeCherney CS, Jackson RV, Sehledon WR, Alexander HN, Island DP, Rivier J, Wale W and Orth DN 1983 Effect of synthetic ovine corticotropin releasing factor: prolonged duration of action and biphasic response of plasma adrenocorticotropin and cortisol. J Clin Endocrinol Metab 57:294298
12. Chan JSD, Lu CL, Seidah NG, Chretien M 1982 Corticotropin releasing factor: Effects on the release of pro-opiomelanocortin (POMC)-related peptides by human anterior pituitary cells in vitro. Endocrinology 11:1388-1390

13. Jackson RV, DeCherney GS, DeBold CR, Sheldon WR, Alexander HN, Rivier J, Vale W, Orth DN 1984 Synthetic ovine corticotropin releasing hormone: simultaneous release of proopiomelanocortin peptides in man. J Clin Endocrinol Metab 58:740-746

14. Hermus ARMM, Pieters GFFM, Smals AGH, Benraad Th J and Kloppenburg PWC 1984 Plasma adrenocorticotropin, cortisol and aldosterone responses to corticotropin releasing factor: modulatory effect of basal cortisol levels. J Clin Endocrinol Metab 58:187-191

15. Orth DN, DeBold CR, DeCherney GS, Jackson RV, Alexander HN, Rivier J, Rivier C, Spiess J and Vale W 1982 Pituitary microadenomas causing Cushing disease respond to corticotropin releasing factor. J Clin Endocrinol Metab 55:1017-1019

16. Müller OA, Stalla GK, vWerder K 1983 Corticotropin releasing factor: a new tool in the differential diagnosis of Cushing syndrome. J Clin Endocrinol Metab 57:227-229

17. Chrousos GP, Schulte HM, Oldfield EH, Gold PW, Cutler GB Jr, Loriaux DL 1984 The corticotropin releasing factor stimulation test. An aid in the evaluation of patients with Cushing syndrome. N Engl J Med 310:622-626

18. Gold PW, Gwirtsman H, Avgerinos PC, Nieman LK, Gallucci WT, Kaye W, Kimerson D, Ebert M, Rittmaster R, Loriaux DL 1986 Abnormal hypothalamic-pituitary-adrenal function in anorexia nervos. $\mathrm{N}$ Engl $\mathrm{J}$ Med 314:1335-1342

19. Nakahara M, Shibasaki M, Shizume K, Kiyosawa $Y$, Odagiri E, Suda $T$, Yamaguki H, Tsushima T, Demura H, Meade T, Wakabayashi T, Ling N 1983 Corticotropin releasing factor test in normal subjects and in patients with hypothalamic-pituitary-adrenal disorders. $J$ Clin Endocrinol Metab 57:963-968

20. Müller OA, Dörr HG, Hageb B, Stalla GK, vWerder K 1982 Corticotropin releasing factor stimulation test in normal controls and in patients with disturbances of the hypothalamo-pituitary-adrenal axis. Klin Wochenschr 60:1485-1492

21. Ross JL, Schulte HM, Gallucci WT, Cutler GB Jr, Loriaux DL, Chrousos GP 1986 Ovine corticotropin releasing hormone stimulation test in normal children. J Clin Endocrinol Metab 62:390-392

22. Copinschi G, Wolter W, Bosson D, Beyloos M, Golstein J, Franckson JRM 1984 Enhanced ACTH and blunted cortisol responses to corticotropin releasing factor in idiopathic panhypopituitarism. J Pediatr 105:591-593

23. Ranke MB, Rosendahl W and Gupta D 1982 Responsiveness of cortisol and dehydroepiandrosterone to ACTH in normal children. Horm Res (Basel) 16:32-41

24. Forest MG, Peretti E de, Bertrand J 1980 Age related shifts in the response of plasma $\Delta_{4}$ - and $\Delta_{5}$-androgens, their $\mathrm{C}_{21}$ precursors and cortisol to ACTH, from infancy to puberty. In: Puberty. Cacciari E, Prader A (eds) Pathophysiology of Academic Press, London, pp 137-155

25. Genazzani AR, Pintor C, Facchinetti F, Inandi P, Maci D, Cordo R 1979 Changes throughout puberty in adrenal secretion after ACTH J Steroid Biochem 11:571-577

26. Reiter EO, Fuldauer GV and Root AW 1977 Secretion of adrenal androgen, dehydroepiandrosterone sulfate, during normal infancy, childhood and adolescence, in sick infants and in children with endocrinologic abnormalities. J Pediatr 90:766-770 